\title{
Laboratory Production of Ergot Alkaloids by Species of Balansia
}

\author{
By CHARLES W. BACON, J. K. PORTER AND J. D. ROBBINS \\ Field Crops Laboratory, U.S. Department of Agriculture, Science and Education Admini- \\ stration, R. B. Russell Agricultural Research Center, Athens, Georgia 30604, U.S.A.
}

(Received 7 November 1978)

\begin{abstract}
Four species of Balansia (clavicipitaceous systemic grass pathogens) isolated from pastures where cattle showed signs of ergot toxicity were grown in culture. Balansia epichloë, one isolate of $B$. claviceps, $B$. henningsiana and two isolates of $B$. strangulans produced conidia in submerged culture during the first stage of a two-stage fermentation procedure. When transferred to a glucose/sorbitol/inorganic salts medium during the second stage, these four species produced ergot alkaloids in stationary cultures. The transfer of fungi cultured in the first medium to the second medium was necessary for alkaloid biosynthesis. One isolate of B. claviceps did not produce alkaloids. Balansia epichloë produced chanoclavine (I), agroclavine, penniclavine, elymoclavine, ergonovine and ergonovinine. Balansia claviceps produced chanoclavine (I), ergonovine and ergonovinine. This is the first report of isolating ergonovine and ergonovinine, two lysergic acid derivatives, from fungi outside the genus Claviceps. Only chanoclavine (I) was identified from extracts of $B$. strangulans and $B$. henningsiana. Chanoclavine (I) and ergonovine were identified from smut grass (Sporobolus poiretii) parasitized by $B$. epichloë, indicating that this endophyte produces alkaloids both in vivo and in vitro.
\end{abstract}

\section{INTRODUCTION}

Several species of Claviceps are associated with toxic effects on cattle grazing on parasitized grasses (for review, see Mantle, 1969). However, many pasture toxicity syndromes of cattle, though resembling those caused by ergot alkaloids, are not caused by species of Claviceps (Yates, 1971; Porter et al., 1975; Bacon et al., 1975; Diener et al., 1976; Mortimer, 1978). Other members of the family Clavicipitaceae causing systemic infections of grasses (Epichloë typhina, Myriogenospora atramentosa and species of Balansia) have also been implicated in the aetiology of ergot-like toxicity syndromes of cattle grazing on infected grasses (Nobindro, 1934; Maag \& Tobiska, 1956; Walker, 1970; Bacon et al., 1975; Bacon et al., 1977; Luttrell \& Bacon, 1977).

The involvement of systemic fungi in pasture toxicity syndromes is complicated by the existence of several biotypes of these grass parasites (Bacon et al., 1977) and by possible seasonal interactions between host and fungus to produce toxic compounds. Moreover, the systemic nature of these fungi increases the difficulties of distinguishing, isolating and identifying toxic fungal compounds from suspect grasses. Nevertheless, the parasitic production of compounds structurally related to alkaloids from Claviceps by these endophytes is suggested by (i) clinical signs observed in cattle, (ii) earlier reports on toxicity of grasses without seedheads and thus no ergot sclerotia and (iii) isolation of indole alkaloids from cultures of these fungi (Porter et al., 1977). In order to establish a definite relationship between pasture toxicities and these clavicipitaceous endophytes, a laboratory procedure is needed for their culture and for assessment of alkaloid production. With the exception of 
Claviceps species, no critical attempts have been made to determine the ability of clavicipitaceous fungi to produce ergot alkaloids. We report here a procedure for production of ergot alkaloids by four species of Balansia.

\section{METHODS}

Organisms. Balansia epichloë (Weese) Diehl, parasitic on smut grass (Sporobolus poiretii), and B. henningsiana (Möller) Diehl, parasitic on Panicum anceps, were obtained from ascospores germinated on a semisynthetic medium (Bacon et al., 1975). Two isolates of B. strangulans (Montagne) Diehl, 233 and 257, parasitic on panic grass (Panicum hians), were obtained from ascospores germinated on corn meal/malt extract (CMM) agar (Bacon et al., 1977). One isolate of B. claviceps Spegazzini, 219, was obtained from E. S. Luttrell, Department of Plant Pathology, University of Georgia, Athens, Ga, U.S.A., and the other isolate, 266, was obtained from conidia germinated on CMM; both isolates were obtained from Chasmanthium laxum. These endophytes were maintained on CMM agar slants at room temperature $\left(24\right.$ to $\left.28^{\circ} \mathrm{C}\right)$. The viability of the fungi declined rapidly if they were stored under refrigeration $\left(4\right.$ to $\left.8{ }^{\circ} \mathrm{C}\right)$.

Media for alkaloid production. A two-stage fermentation procedure was used to produce alkaloids. First, the fungi were incubated in $50 \mathrm{ml}$ of sporulation medium M102 (Bacon et al., 1977) for $10 \mathrm{~d}$ on a gyratory shaker (150 rev. $\mathrm{min}^{-1}, 1 \mathrm{~cm}$ circular orbit) at $24^{\circ} \mathrm{C}$ in $125 \mathrm{ml}$ triple-baffled shake flasks. Then, for the second stage of fermentation, during which alkaloid biosynthesis occurred, the fungi were incubated in modified medium SM (Abe et al., 1969) containing (per litre distilled water): sorbitol, $100 \mathrm{~g}$; glucose, $40 \mathrm{~g}$; succinic acid, $10 \mathrm{~g} ; \mathrm{KH}_{2} \mathrm{PO}_{4}, 1.0 \mathrm{~g} ; \mathrm{MgSO}_{4} .7 \mathrm{H}_{2} \mathrm{O}, 0.3 \mathrm{~g} ;$ yeast extract, $1.0 \mathrm{~g} ; \mathrm{FeSO}_{4} .7 \mathrm{H}_{2} \mathrm{O}, 0.1 \mathrm{mg} ; \mathrm{CuSO}_{4} .5 \mathrm{H}_{2} \mathrm{O}$, $0.01 \mathrm{mg} ; \mathrm{ZnSO}_{4} .7 \mathrm{H}_{2} \mathrm{O}, 0.01 \mathrm{mg} ; \mathrm{MnSO}_{4} . \mathrm{H}_{2} \mathrm{O}, 0.001 \mathrm{mg}$. The $\mathrm{pH}$ was adjusted to $5 \cdot 6$ with $\mathrm{NH}_{4} \mathrm{OH}$. Medium SM $(100 \mathrm{ml})$ in $500 \mathrm{ml}$ triple-baffled cotton-stoppered flasks was inoculated with $2 \mathrm{ml}$ of sporulating culture from medium M102. The flasks were incubated at $24^{\circ} \mathrm{C}$ for $10 \mathrm{~d}$ on a gyratory shaker and were then removed from the shaker and incubated as stationary cultures until harvested. Medium-scale production of alkaloids for isolation and chemical identification was accomplished using $500 \mathrm{ml}$ medium SM in Pyrex carboys (19 l) stoppered with cotton plugs. The carboys were inoculated with $10 \mathrm{ml}$ of spores from medium M102 and incubated for 7 weeks at $26^{\circ} \mathrm{C}$ as stationary cultures. All cultures were incubated in the dark.

Analytical methods. Dry weights were determined on mycelium that had been separated from the culture filtrate by vacuum filtration through Whatman no. 4 filter paper, washed with distilled water and dried in a forced air drying oven at $90^{\circ} \mathrm{C}$ for $24 \mathrm{~h}$. Inorganic phosphate was assayed by the method of Martin \& Doty (1949). Glucose was determined by the $o$-toluidine procedure (Hyvarinen \& Nikkila, 1962). Sorbitol was measured as its trifluoroacetyl derivative by gas-liquid chromatography (Sullivan \& Schewe, 1977) on columns containing $3 \%$ OV-225 on Chromosorb W(HP), 80 to 100 mesh.

Alkaloid analysis. Alkaloids were determined by adding $0.2 \mathrm{ml} 10 \mathrm{M}-\mathrm{NaOH}$ to $10 \mathrm{ml}$ culture filtrate and extracting the alkaloids with $25 \mathrm{ml} \mathrm{CHCl}_{3}$. The $\mathrm{CHCl}_{3}$ extract was evaporated to dryness on a rotary evaporator $\left(40^{\circ} \mathrm{C}\right)$ and the residue was dissolved in $2 \mathrm{ml} 2 \%(\mathrm{w} / \mathrm{v})$ tartaric acid. The tartaric acid extracts were diluted and the total alkaloid content was measured colorimetrically at $590 \mathrm{~nm}$ (Michelon \& Kelleher, 1963) using a standard solution of ergonovine maleate as a reference.

Chemical separation and identification of alkaloids were done with larger volumes of media using the techniques described above, except that the $\mathrm{pH}$ of the tartaric acid extract was adjusted to between 8 and 9 with $\mathrm{NaOH}$ and this basic tartaric acid extract was then further extracted with $\mathrm{CHCl}_{3}$. The $\mathrm{CHCl}_{3}$ extract was evaporated to dryness on the rotary evaporator and the residue was taken up in $20 \mathrm{ml} \mathrm{CHCl}_{3}$. The alkaloids were separated by thin-layer chromatography of the chloroform extract on silica gel GF254 developed with chloroform/methanol $(90: 10, \mathrm{v} / \mathrm{v})$; they were viewed under ultraviolet light and sprayed with a $p$ dimethylaminobenzaldehyde solution (Stahl, 1969). The identity of the alkaloids was established by cochromatography with reference standards, and by ultraviolet and low resolution mass spectral analyses (Porter et al., 1978).

Smut grass leaves (S. poiretii) parasitized by B. epichloe were collected and lyophilized; the black stromata of the fungus located on the adaxial leaf surfaces were used to indicate infection. Alkaloids were extracted from the lyophilized grass $(250 \mathrm{~g})$ according to the procedure of Stoll et al. (1954) and analysed as described above.

\section{RESULTS}

Sporulation by Balansia epichloë, $B$. claviceps $219, B$. strangulans and $B$. henningsiana began after $7 \mathrm{~d}$ incubation on medium M102 and reached a maximum after $10 \mathrm{~d}$; the average spore concentration for these four species was $10^{6} \mathrm{ml}^{-1}$. Balansia claviceps 266 did not sporulate on medium M102 or on a variety of other media.

The fermentation procedure used demonstrated that the isolates of the four species of 
Table 1. Alkaloid production by species of Balansia in culture

Fungi were incubated according to the two-stage fermentation procedure and harvested when total alkaloids were maximum. Alkaloids were extracted and identified as described in Methods.

\begin{tabular}{|c|c|c|c|c|c|c|}
\hline \multirow[b]{2}{*}{ Fungus } & \multirow[b]{2}{*}{$\begin{array}{l}\text { Incubation } \\
\text { time } \\
\text { (d) }\end{array}$} & \multicolumn{4}{|c|}{ Alkaloids } & \multirow[b]{2}{*}{$\begin{array}{l}\text { Maximum } \\
\text { total alkaloids } \\
\quad\left(\mathrm{mg} \mathrm{l}^{-1}\right)\end{array}$} \\
\hline & & $\begin{array}{l}\text { Chano- } \\
\text { clavine (I) }\end{array}$ & $\begin{array}{c}\text { Ergono- } \\
\text { vine }\end{array}$ & $\begin{array}{l}\text { Ergono- } \\
\text { vinine }\end{array}$ & $\begin{array}{l}\text { Agro- } \\
\text { clavine }\end{array}$ & \\
\hline B. epichlö̈ & 28 & + & + & + & + & 390.00 \\
\hline$B$. henningsiana & 36 & $+*$ & - & - & - & 6.95 \\
\hline B. strangulans 233 & 38 & $+*$ & - & - & - & 85.00 \\
\hline B. strangulans 257 & 38 & $+*$ & - & - & - & $158 \cdot 00$ \\
\hline B. claviceps 266 & 28 & - & - & - & - & 0.00 \\
\hline B. claviceps 219 & 28 & + & + & + & - & $170 \cdot 25$ \\
\hline
\end{tabular}

+ , Present; - not detected.

* Additional clavine-type alkaloids were detected but their structures were not determined.

Table 2. Alkaloid production by Balansia epichloë in single- and two-stage laboratory cultures

In single-stage culture (M102; SM), the fungus was incubated in triplicate flasks containing $100 \mathrm{ml}$ medium M102 or SM for 28 d. In two-stage culture (SM to M102; M102 to SM), the fungus was incubated for $10 \mathrm{~d}$ in either SM or M102 and then $1 \mathrm{ml}$ inocula were transferred to triplicate flasks containing $100 \mathrm{ml}$ of the other medium for $28 \mathrm{~d}$.

$\begin{array}{lcc}\text { Culture medium } & \begin{array}{c}\text { Mycelial dry } \\ \text { wt }(\mathrm{mg})\end{array} & \begin{array}{c}\text { Mean alkaloid } \\ \text { yield }\left(\mathrm{mg} \mathrm{1}^{-1}\right)\end{array} \\ \text { M102 } & 210 & 0.00 \\ \text { SM } & 161 & 0 \cdot 25 \\ \text { SM to M102 } & 197 & 0.00 \\ \text { M102 to SM } & 176 & 394.50\end{array}$

Balansia tested varied in their ability to produce alkaloids (Table 1). Not only did Balansia epichloë produce the highest total amount of alkaloids, but it also produced the greatest variety of ergot alkaloids. Medium-scale production of alkaloids from B. epichloë resulted in the isolation and identification of two more minor ergot alkaloids - elymoclavine and penniclavine - and another unidentified clavine alkaloid. In addition to chanoclavine (I), the total alkaloid fraction of $B$. henningsiana and $B$. strangulans contained several minor but unidentified clavine-type alkaloids. Smut grass parasitized by $B$. epichloë contained $17 \mathrm{mg}$ total alkaloids $\mathrm{kg}^{-1}$. The major alkaloids identified from the grass were chanoclavine (I) $\left(16.0 \mathrm{mg} \mathrm{kg}^{-1}\right)$ and ergonovine $\left(0.48 \mathrm{mg} \mathrm{kg}^{-1}\right)$. Several minor alkaloids extracted from the grass were not identified.

Since $B$. epichloë produced the largest amount of alkaloids, the results of studies of some of the requirements for alkaloid biosynthesis on medium SM are presented for this species and references to the other species are made only when different results were obtained. The use of medium M102 followed by medium SM was essential for high yields of alkaloids from B. epichloë (Table 2) and for alkaloid production by the other species of Balansia. Alkaloids were not produced when the fungi were cultured for $10 \mathrm{~d}$ on medium M102 and then transferred to fresh M102; nor were they produced when this type of experiment was done using only medium SM. When medium M38 (Bacon et al., 1975) and a soluble starch medium (Porter et al., 1977) were used instead of M102 or SM in various combinations, alkaloids were not produced. The yield of alkaloids was greatly reduced ( 60 to $80 \%$ ) when the fungi were incubated as submerged cultures in medium SM (data not shown). Incubation on the gyratory shaker for $10 \mathrm{~d}$ increased the rate of mycelial growth, thus reducing the time before maximum alkaloid production.

In the alkaloid-producing medium SM, maximum alkaloid yields from $B$. claviceps $\left(190 \mathrm{mg}^{-1}\right)$ and $B$. epichloë $\left(390 \mathrm{mg} \mathrm{l}^{-1}\right)$ were obtained after $28 \mathrm{~d}$ incubation (Table 1 and 


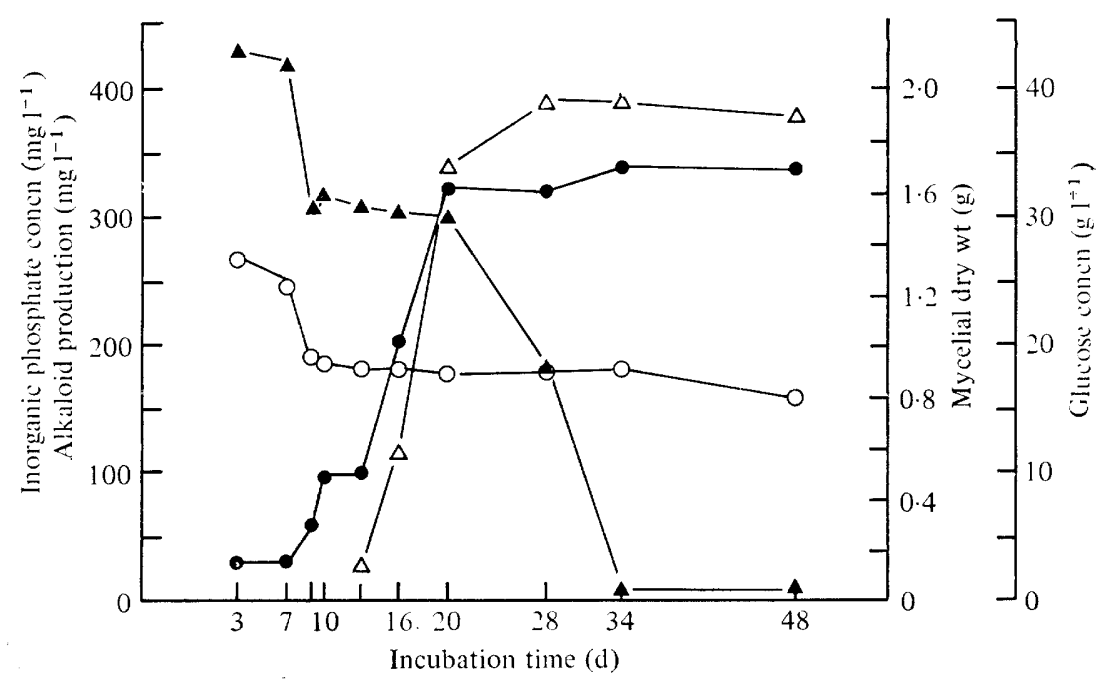

Fig. 1. Changes in mycelial dry weight $(\bullet)$, production of alkaloids $(\triangle)$, glucose concentration $(\Delta)$ and inorganic phosphate concentration $(O)$ during growth of Balansia epichloë in $100 \mathrm{ml}$ medium $\mathrm{SM}$ in $500 \mathrm{ml}$ flasks; the fungus was grown in submerged culture during the first $10 \mathrm{~d}$.

Table 3. Effect of substituting various carbon sources in medium SM on growth and alkaloid production by $B$. epichloë

Cultures were analysed after $28 \mathrm{~d}$ of two-stage culture in $100 \mathrm{ml}$ medium SM.

$\begin{array}{lrcc}\text { Carbon source } & \begin{array}{r}\text { Concn } \\ \left(\mathrm{g} \mathrm{l}^{-1}\right)\end{array} & \begin{array}{c}\text { Mycelial dry } \\ \text { wt }(\mathrm{mg})\end{array} & \begin{array}{c}\text { Total alkaloids } \\ \left(\mathrm{mg} \mathrm{l}^{-1}\right)\end{array} \\ \text { Glucose/sorbitol } & 50: 100 & 450 \cdot 80 & 403 \cdot 0 \\ \text { Glucose } & 50 & 458 \cdot 80 & \text { ND } \\ \text { Glucose } & 100 & 335 \cdot 08 & \text { ND } \\ \text { Sorbitol } & 100 & 58 \cdot 27 & 1 \cdot 6 \\ \text { Glucose/mannitol } & 50: 100 & 156 \cdot 24 & 397 \cdot 0 \\ \text { Mannitol } & 100 & 61 \cdot 37 & \text { ND } \\ \text { Sucrose } & 100 & 118 \cdot 44 & 3 \cdot 0 \\ \text { Sucrose/sorbitol } & 100: 100 & 294 \cdot 27 & 5 \cdot 0 \\ & \text { ND, Not detected. } & \end{array}$

Fig. 1). Maximum alkaloid production (Table 1) occurred within 38 and $36 \mathrm{~d}$ for $B$. strangulans and $B$. henningsiana, respectively. Accumulation of alkaloids paralleled the growth phase, and production levelled off when the concentration of glucose in the medium began its second decline(Fig. 1). High concentrations of inorganic phosphate and sorbitol remained in the medium at the end of fermentation for all species. Although sorbitol was not used during fermentation, its presence along with glucose was necessary for high levels of alkaloid production; it could be replaced by mannitol, but this was accompanied by a substantial growth reduction (Table 3 ). When sorbitol was the sole source of carbon, $20 \%$ was used after $28 \mathrm{~d}$ incubation and alkaloids were not produced. Negative results were also obtained when mannitol was the sole carbon source. No alkaloids were produced during the $28 \mathrm{~d}$ incubation period when glucose at either normal or twice normal concentration was used as the sole carbon source (Table 3). In a separate experiment (data not shown) in which glucose $\left(50 \mathrm{~g} \mathrm{l}^{-1}\right)$ was the sole carbon source, the glucose was depleted after $8 \mathrm{~d}$ incubation, rather than after $34 \mathrm{~d}$ as it was when both glucose $\left(40 \mathrm{~g} \mathrm{l}^{-1}\right)$ and sorbitol $\left(100 \mathrm{~g} \mathrm{l}^{-1}\right)$ were present (Fig. 1). However, reduced yields of alkaloids $\left(70 \mathrm{mg} \mathrm{l}^{-1}\right)$ were obtained in media containing glucose as the only carbon source when the incubation period 
Table 4. Effect of inorganic phosphate on alkaloid production by B. epichloë

Triplicate cultures were analysed after $28 \mathrm{~d}$ growth in $100 \mathrm{ml}$ medium $\mathrm{SM}$ containing different

\begin{tabular}{lcc}
\multicolumn{3}{c}{ concentrations of $\mathrm{KH}_{2} \mathrm{PO}_{4}}$. \\
$\begin{array}{c}\text { Mycelial } \\
\text { dry wt } \\
\mathrm{KH}_{2} \mathrm{PO}_{4} \text { concn } \\
\left(\mathrm{g} \mathrm{l}^{-1}\right)\end{array}$ & $\begin{array}{c}\text { Total } \\
\text { alkaloids } \\
\left(\mathrm{mg} \mathrm{l}^{-1}\right)\end{array}$ \\
0.025 & $219 \cdot 27$ & 4.72 \\
0.500 & 410.72 & 67.34 \\
1.000 (control) & 439.62 & 380.42 \\
2.000 & 484.71 & 376.91
\end{tabular}

was extended to a total of $45 \mathrm{~d}$. Sucrose supported growth and low production of alkaloids when used alone or in combination with sorbitol. When succinic acid was omitted from medium SM, alkaloids were not produced, whereas mycelial yields were comparable to those of controls. Maximum amounts of alkaloids were produced by all species with succinic acid at $10 \mathrm{~g} \mathrm{l}^{-1}$. These fungi did not produce alkaloids when succinic acid was replaced with equimolar concentrations of glutamic acid or when succinic acid was added to medium M102 and extracted for alkaloids after a $28 \mathrm{~d}$ single-stage fermentation as described in Table 2.

The concentration of inorganic phosphate in medium SM was varied to determine its effect on alkaloid yield (Table 4). With $\mathrm{KH}_{2} \mathrm{PO}_{4}$ at $2 \mathrm{~g} \mathrm{l}^{-1}$, alkaloid production was no different from normal (i.e. with $1 \mathrm{~g} \mathrm{KH}_{2} \mathrm{PO}_{4} \mathrm{1}^{-1}$ ). Alkaloid yields were reduced at concentrations of phosphate below the control level. Thin-layer chromatography of the alkaloid fractions from media low in phosphate showed that only chanoclavine (I) was produced. Alkaloid fractions from media containing normal and high levels of phosphate consisted of the ergot alkaloids described for B. epichloë (Table 1). Addition of tryptophan $\left(0.001 \mathrm{~g} \mathrm{l}^{-1}\right)$ to medium SM with normal, high $\left(2 \mathrm{~g} \mathrm{l}^{-1}\right)$ or low $\left(0 \cdot 025 \mathrm{~g} \mathrm{l}^{-1}\right)$ concentrations of $\mathrm{KH}_{2} \mathrm{PO}_{4}$ led to a decrease in total alkaloid yield $\left(130 \mathrm{mg} \mathrm{l}^{-1}\right)$ in each case. Alkaloids were not produced when tryptophan was added at 0.01 or $0.1 \mathrm{~g}^{-1}$ to medium SM with normal, high or low inorganic phosphate concentrations. The effects of tryptophan on alkaloid production by $B$. henningsiana, $B$. claviceps and $B$. strangulans were not determined.

\section{DISCUSSION}

We isolated chanoclavine (I), agroclavine, penniclavine and elymoclavine, all clavinetype ergot alkaloids commonly found in species of Claviceps, from cultures of B. epichloë. These alkaloids were also isolated by other workers from cultures of Aspergillus fumigatus (Spilsbury \& Wilkinson, 1961), Penicillium concavo-rugulosum (Abe et al., 1969) and $P$. chermesinum (Agurell, 1964). Chanoclavine (I) was also produced by $B$. claviceps, $B$. henningsian $a$ and $B$. strangulans. Additional minor alkaloids produced by these species were not completely identified, but mass spectral analysis indicated that they were of the clavine type. The isolation of ergonovine and ergonovinine from cultures of $B$. claviceps and $B$. epichloe is the first demonstration of lysergic acid derivatives in fungi outside the genus Claviceps. It suggests that the ability to synthesize these lysergic acid derivatives resides more generally within the family Clavicipitaceae, not just in the genus Claviceps. Peptide-type alkaloids were not detected in culture extracts of Balansia. These species of Balansia might therefore be placed under the second biochemical grouping established for ergot fungi the $C$. paspali type that produce the clavine alkaloids and simple lysergic acid derivatives but no peptide alkaloids (Gröger, 1972). Interesting in this respect is the concept that, taxonomically, the C. paspali group is intermediate between the Balansia and the C. purpurea groups, but is more closely related to the Balansia group (Gröger, 1972).

Production of ergot alkaloids in culture by species of Balansia has several requirements. 
The fungi must first be cultured in a nutrient medium in which they grow and sporulate, and then transferred to a different growth medium in which they produce alkaloids. These species of Balansia produced spores on medium M38 (Bacon et al., 1975) which were morphologically identical to those produced on medium M102, but subsequent transfer to medium SM did not result in alkaloid production. Thus the process of sporulation is not essential for alkaloid biosynthesis. The nature of the differences between the fungi grown on these two media is unknown. Large quantities of sorbitol remained in the medium after fermentation and it may be used as a growth promoter, as is inositol in many fungi. If it does function as a growth promoter, the small amount utilized could not be determined by our method of analysis. Glucose is the main source of carbon for these fungi in medium SM. The requirement for sorbitol or mannitol, the continued increase in mycelial dry weight even though glucose utilization is reduced, and the delay of maximum alkaloid synthesis until glucose enters a second period of rapid utilization characterized by no further increase in mycelial dry weight suggest that alkaloid production is controlled by a growth-linked suppression mechanism (Bu'Lock, 1965), which is described as regulated by catabolite repression in Claviceps, Cephalosporium and other fungi by Drew \& Demain (1977). Additional evidence needed to support this generality (other means of measuring growth, and the nature of the limiting nutrient) was not obtained in this study. The relationship of inorganic phosphate concentration to alkaloid synthesis in B. epichloe is the reverse of that in Claviceps species. In submerged cultures of Claviceps, uptake of inorganic phosphate was rapid and complete (Arcamone et al., 1970; Banks et al., 1974). High concentrations of phosphate depressed alkaloid biosynthesis, the effect being related to the concentration of tryptophan (Robbers $e$ t al., 1972). The rapid drop in phosphate concentration seen in our study during the first $10 \mathrm{~d}$ fermentation, when the fungi were cultured submerged, indicates that the submerged culture of Balansia leads to an initial uptake of phosphates. Tryptophan was reported to increase the yield of alkaloids in certain species of Claviceps (Robbers et al., 1972). The addition of tryptophan to medium SM did not increase alkaloid yield and any relationships of tryptophan to phosphate utilization and alkaloid biosynthesis in these Balansia species are unknown.

Variations between two isolates of $B$. strangulans and two of $B$. claviceps when each species was obtained from identical grass species from the same location indicate that the distribution of ergot alkaloids within a pasture might not be uniform and, indeed, that some of the grass might not be toxic. Thus, the presence of endophytes would not necessarily indicate toxicity. A more extensive survey of isolates of endophytes from individual pastures would determine the degree of variability. The isolation of ergonovine and chanoclavine (I) from randomly collected $B$. epichloe -infested smut grass indicated that at least two of the alkaloids are produced in vivo and established a relationship between the systemic species on this grass and pasture toxicity. Since the parasitized smut grass was collected during the time when black stromata were visible on the leaves (end of the growing season), we have no indication as to the amount and types of alkaloids present in the grass throughout the growing season. Since each species of Balansia parasitizes several grass species, a comparative survey of isolates from different hosts would indicate whether the host influences alkaloid production, as reported in Claviceps (Gröger, 1972). The biological activities of the ergot alkaloids produced by these Balansia species are known. The clavine alkaloids, depending on the concentration, produce hyperpnoea, mydriasis, anxiety (Yui \& Takeo, 1958), prolactin inhibition (Cassady \& Floss, 1977), nidation and death in animals (Mantle, 1969). The toxicity of the lysergic acid derivatives to domestic animals has been reviewed by Burfening (1973) and Mantle (1969). The present results, therefore, indicate that the production of the ergot alkaloids by $B$. epichloë, $B$. claviceps, $B$. henningsiana and $B$. strangulans may be involved in the many ergot-type cattle toxicity syndromes in pastures where species of Claviceps are absent. 
We thank F. W. Gould and W. H. Duncan for identifying the grasses; E. S. Luttrell, University of Georgia, for supplying B. claviceps 219 ; R. M. Bennett, J. Robbins and C. Groover for technical assistance; and R. W. Roncadori, University of Georgia, for use of greenhouse facilities to grow parasitized grasses.

\section{REFERENCES}

Aвe, M., Оhмомo, S., Ohashi, T. \& Tabuchi, T. (1969). Isolation of chanoclavine-(I) and two new interconvertible alkaloids, rugulovasine $\mathrm{A}$ and $\mathrm{B}$, from the cultures of Penicillium concavo-rugulosum. Agricultural and Biological Chemistry 33, 469-471.

Agurell, S. (1964). Costoclavine from Penicillium chermesinum. Experientia 20, 25-26.

Arcamone, F., Cassinelli, G., Ferni, G., Penco, G., Pennella, P. \& Pol, C. (1970). Ergotamine production and metabolism of Claviceps purpurea 275 FI in stirred fermenters. Canadian Journal of Microbiology 16, 923-931.

Bacon, C. W., Porter, J. K. \& Robins, J. D. (1975). Toxicity and occurrence of Balansia on grasses from toxic fescue pastures. Applied Microbiology 29, 553-556.

Bacon, C. W., Porter, J. K., Robbins, J. D. \& LutTrell, E. S. (1977). Epichloë typhina from toxic tall fescue grasses. Applied and Environmental Microbiology 34, 576-581.

Banks, G. T., Mantle, P. G. \& Szczyrbak, C. A. (1974). Large-scale production of clavine alkaloids by Claviceps fusiformis. Journal of General Microbiology 82, 345-361.

Bu 'Lock, J. D. (1965). Aspects of secondary metabolism in fungi. In Biogenesis of Antibiotic Substances, pp. 61-71. Edited by Z. Vanek \& Z. Hostalek. New York \& London: Academic Press.

Burfening, P. J. (1973). Ergotism. Journal of the American Veterinary Medical Association 163, 1288-1290.

Cassady, J. M. \& Floss, H. G. (1977). Ergolinea as potential prolactin and mammary tumor inhibitors. Lloydia 40, 90-106.

Diener, U. L., MorGan-Jones, G., Wagener, R. E. \& DAvis, N. D. (1976). Bermuda grass tremors in Alabama cattle in 1974. In Proceedings of Third International Biodegradation Symposium, pp. 673678. Edited by J. M. Sharpely \& A. M. Kaplan. London: Applied Science Publishers.

Drew, S. W. \& Demain, A. L. (1977). Effect of primary metabolites on secondary metabolism. Annual Review of Microbiology 31, 343-356.

GrögER, D. (1972). Ergot. In Microbial Toxins, vol. 8, pp. 321-323. Edited by S. Kadis, A. Ciegler \& S. J. Ajl. New York \& London: Academic Press.

Hyvarinen, A. \& Nikkila, E. (1962). Specific determination of blood glucose with $o$-toluidine. Clinica chimica acta 7, 140-143.

LutTrell, E. S. \& BACON, C. W. (1977). Classification of Myriogenospora in the Clavicipitaceae. Canadian Journal of Botany 55, 2090-2097.

MAGG, D. D. \& TobiskA, M. S. (1956). Fescue lameness in cattle. II. Ergot alkaloids in tall fescue grass. American Journal of Veterinary Research 17, 201-204.
Mantle, P. G. (1969). The role of alkaloids in the poisoning of mammals by sclerotia of Claviceps spp. Journal of Stored Products Research 5, 237244.

Martin, J. B. \& Doty, D. M. (1949). Determination of inorganic phosphates. Analytical Chemistry 21, 965-967.

Mrchelon, L. E. \& Kelleher, W. J. (1963). The spectrophotometric determination of ergot alkaloids. A modified procedure employing paradimethylaminobenzaldehyde. Lloydia 26, 192-201.

Mortimer, P. H. (1978). Perennial ryegrass staggers in New Zealand. In Effects of Poisonous Plants on Livestock, pp. 353-361. Edited by R. F. Keeler, K. R. van Kampen \& L. F. James. New York and London: Academic Press.

NoBINDRo, U. (1934). Grass poisoning among cattle and goats in Assam. Indian Veterinary Journal 10, 235-236.

Porter, J. K., Bacon, C. W., Robbins, J. D. \& Higman, H. C. (1975). A field indicator in plants associated with ergot-type toxicities in cattle. Journal of Agricultural and Food Chemistry 23, $771-775$.

Porter, J. K., Bacon, C. W., Robbins, J. D., HimMelsBaCH, D.S. \& Higman, H. C. (1977). Indole alkaloids from Balansia epichloë (Weese). Journal of Agricultural and Food Chemistry 25, 88-93.

Porter, J. K., Bacon, C. W. \& Robbins, J. D. (1978). Lysergic acid amide derivatives from Balansia epichloë (Clavicipitaceae). Lloydia (in the Press).

RobBers, J. F., RobertSON, L. W., HoRnemanN, K. M., JindRA, A. \& Floss, H. G. (1972). Physiological studies on ergot: further studies on the induction of alkaloid synthesis by tryptophan and its inhibition by phosphate. Journal of Bacteriology 112, 791-796.

Spilsbury, J. F. \& Wilkinson, S. (1961). The isolation of festuclavine and two new clavine alkaloids from Aspergillus fumigatus Fres. Journal of the Chemical Society, 2085.

Stahl, E. (1969). Thin-layer Chromatography: $A$ Laboratory Handbook, p. 689. New York: Springer Verlag.

Stoll, A., Brack, A., Kobel, H., Hofmann, A. \& Brunner, R. (1954). Die Alkaloide eines Mutterkornpilzes von Pennisetum typhoideum Rich. und deren Bildung in saprophytischer Kultur. Helvetica chimica acta 37, 1815-1825.

Sullivan, J. E. \& Schewe, L. R. (1977). Preparation and gas chromatography of highly volatile trifluoroacetylated carbohydrates using $N$-methyl bis(tri-fluoroacetamide). Journal of Chromatographic Science 15, 196-197.

WALKER, J. (1970). Systematic fungal parasite of Pholaris tuberosa in Australia. Search 1, 81-83. 
YATES, S. G. (1971). Toxin-producing fungi from fescue pastures. In Microbial Toxins, vol. 7, pp. 191-206. Edited by S. Kadis, A. Ciegler \& S. J. Ajl. New York \& London: Academic Press.
YUI, T. \& TAKeO, Y. (1958). Neuropharmacological studies on a new series of ergot alkaloids. Japanese Journal of Pharmacology 1, 157-161. 